\title{
Glamorous intellectuals: Portraits of pepaideumenoi in the second and third centuries AD
}

\author{
BARBARA E. BORG
}

One of the most striking features of the Roman Empire is the importance given to the self-representation of members of the élite - and not just the élite - in statues and portrait images. Public places and buildings, as well as houses, villas, borti, and tombs, were filled with painted, sculpted, and cast portraits which could be dedicated by a city, province, collegium, friend or admirer, or a family member. The monuments themselves conveyed information about the person honoured, the reason for the dedication, his or her status, offices, virtues etc. Inscriptions, dress and posture, as well as the portrait head, all worked together to communicate their messages to the viewer. For the historian, such monuments are a highly valuable source of information about the norms and ideals on which the society was built. If it is indeed true that the strange intellectuals whom Philostratus called sophists and honoured with biographies, incorporated ideals accepted and acknowledged by the rest of the Roman élite, there should be a good chance of finding these ideals expressed in portraiture as well.

Paul Zanker, in his book The Mask of Socrates, has elaborated on the much older idea that the fashion of wearing a beard, made popular by the emperor Hadrian, demonstrated an affinity with Greek philosophy on the part of the person who wore it. Zanker began with the chronological coincidence of two phenomena. On the one hand, for a Roman of the first centuries BC and AD, Greek paideia, and in particular Greek philosophy, was a somewhat precarious occupation and acceptable mainly in the realm of otium. During this same period, portraits even of known intellectuals presented the same clean-shaven and austere look as that of any other distinguished Roman citizen (fig. 2). 'This attitude changed over time, and with Hadrian (fig. 5-6), so he argued, both intellectual occupations and wearing a full beard became acceptable not only for adult men but even for the Emperor, so that, from then on, wearing a beard became a sign of ambition in the field of Greek paideia. Moreover, the fact that beards became

1 Zanker, 1995, 190-206. 
longer and longer in the course of the second century $\mathrm{AD}$, Zanker interprets not only as confirmation of his hypothesis (the intellectual's image becoming more consistent over time) but as evidence of a particular focus on philosophical education. $^{2}$ However, his line of reasoning encounters some methodological problems arising from two different aspects of the argument: interpretation of iconographical features on the one hand, and the concept of philosopher on the other. $^{3}$

As R.R.R. Smith pointed out, ${ }^{4}$ no single iconographical feature usually taken as an indication of philosophical ambition is as unambiguous as suggested, not even the beard, which is often interpreted as the most decisive signal. Although a Greek philosopher typically wears a beard, there is no indication that longer beards are more philosophical than shorter ones - think only of Aristotle. Men without any intellectual interest at all, like, for instance, Hadrian's successors Antoninus Pius or Lucius Verus (fig. 7), do wear beards as well. Even Hadrian himself was not particularly interested in philosophy, but in the Greeks and Greek culture in a much more general sense. ${ }^{5}$ In his portraits (fig. 5-6), he neither wears the bimation so typical of philosophers, ${ }^{6}$ nor does he imitate any particular

2 Zanker, 1995, 206-221.

3 Cf. Smith, 1998, and Smith, 1999. I shall not repeat the whole discussion here but limit myself to those aspects particularly relevant for the present argument.

4 Smith, 1999, 453.

5 Woolf, 1994.

6 Quite often, a statue of Hadrian from the temple of Apollo in Cyrene (now London, British Museum no. 1381) is taken not only as the exception to the rule but as proof that emperors were indeed presented in the bimation from Hadrian onwards (cf. Ewald, 1999a, 14; Zanker, 1995, 209 fig. 115). To this example should be added a statue of Nerva from the same temple (now London, British Museum no. 1404; for the two London statues see Rosenbaum, 1960 , 46-48 no. 23 pls. 19 and 26, 3; 51-52 no. 34 pls. 26-27; $81-82$ no. 123 pl. 67, 4) and a statue still in Cyrene representing Marcus Aurelius (Archaeological Museum, without no?? cf. Bonacasa - Ensoli [eds.], 2000, 76). However, as Jane Fejfer kindly pointed out to me, all three statues seem to be late antique pasticci. Rosenbaum (loc. cit.) notes that the statues were restored from separate pieces and fragments but is not entirely clear about when this assemblage was made. Referring to Bagnani, 1921, 323, who suggests that the antique restoration of over 20 statues found in Cyrene was part of a larger Hadrianic restoration program after ravages during the Jewish revolt of $116 \mathrm{AD}$, Rosenbaum suggests a Hadrianic date for the restoration of Nerva as well. However, in the light of the restored statues of Hadrian and Marcus this is hardly likely. The case of Marcus is particularly telling. As noted in Bonacasa - Ensoli [eds.] loc. cit., the statue was assembled by using a good second century portrait of the emperor and a female statue reworked into something vaguely resembling a bimation statue. That this reconstruction must have taken place in Late Antiquity, most probably in the second half of the fourth century, can be demonstrated by a very similar pasticcio: a reworked female statue was joined with an equally reworked head of Tiberius and turned into the portrait of the official Sufenas Proculus (Bonacasa - Ensoli [eds.], 2000, 126). Although these latter statues were not 
Greek philosopher's hairstyle. ${ }^{7}$ On the contrary, whereas these philosophers mostly wear their hair in a rather unassuming way, Hadrian's hair is styled in luxurious waves running from the back of his head to his forehead, where it is coiled up into neat and rather pretentious curls, doubtless with the help of curling-tongs. This hairstyle has its precursors in the Claudian and Neronian age, where it is typical of children and young people both male and female. ${ }^{8}$ Nero's famous coma in gradus formata (Suet. Nero 51) is a variation of it (fig. 1), as is the coiffure coma in anulos with its tight curls instead of the curved strands around the forehead. ${ }^{9}$ From Nero's time onwards, these hairstyles are sometimes combined with a beard, as in the case of Nero himself, ${ }^{10}$ or, later, Domitian. ${ }^{11}$

In the first century, the conservative Roman élites looked upon this extravagant outer appearance with much scepticism and even criticism, just as they did other aspects of luxuria - Greek and otherwise. ${ }^{12}$ Until the end of the first century, the hairstyles just described are typical of the jeunesse dorée of the Neronian and Flavian periods, condemned by Quintilian, Suetonius, Martial, and others, because of the time-consuming styling procedure which they required. ${ }^{13}$ Accordingly, both Galba and the more fortunate Vespasian presented themselves with short-cropped hair, and without trying to hide their more or less advanced baldness. ${ }^{14}$ The case of the beard is not as clear, but extant portraiture and the phrase

found in the same place as Nerva and Hadrian, all four may well belong to a Late Antique restoration program after the earthquake of $365 \mathrm{AD}$. However this may be, it should be noted that even if the Nerva and Hadrian in bimation were genuine pieces from the second century they would be exceptions rather than the rule. On the significance of the bimation see below.

7 For imitations of classical Greek hairstyles, cf. von den Hoff, 1994, 18-20; Krumeich, this volume.

8 Amedick, 1991; Cain, 1993, 58-68.

9 Cain, 1993, 70-74; on Nero's hairstyle see Bergmann, 1998, 148-149; 174-177, and the summary in Schneider, 2003, with bibliography. .

10 Hiesinger, 1975; Cain, 1993, 102; Bergmann, 1998, 147-149.

11 Cain, 1993, 102. There are also earlier examples of portraits with beards but different hairstyles, but on young men only, cf. Cain, 1993, 100-102 with further references. It is therefore remarkable that from Nero onwards emperors as well as other men wear beards as adults as well, cf. portraits on the Flavian Cancelleria Reliefs (Bonnano, 1976, pls. 121-122; 125; 128), the Arch of Trajan at Benevent (Bonanno, 1976, pls. 158-159;172-173; 175; 177) and lictores on a relief in Palaestrina (Musso - Pfanner, 1987, with fig. 2 pl. 1 [wrong way round]).

12 Petrochilos, 1974, 35-53; Balsdon, 1979, esp. 30-54; Beagon, 1992, 17-20 on Pliny; WallaceHadrill, 1990; Edwards, 1993, in part. 92-97. For the attitude towards other aspects of Greek culture during the Republican era see Gruen, 1990.

13 E.g. Quint. Inst. 12.10.47; Suet. Nero 51; Sen. Lp. 10.12.3; Mart. 8.52; cf. collection of sources in $R A C 4,1959,619-650$, particularly 632-633 (on hair styles) s.v. Heffeminatus (H. Herter); cf. Cain, 1993, 89-92.

14 Schneider, 2003, 69-74 with bibl. 
barbatuli juvenes indicates that wearing a beard was long regarded as a custom peculiar to the young. ${ }^{15}$ The full beard of an adult associated with Greece, was apparently not acceptable at Rome, and even philosophers like Seneca did not wear beards (fig. 2). ${ }^{10}$ With time, however, these conservative attitudes seem to have become less dominant. Already in the Flavian period, there is a considerable increase in the number of coma in gradus and in anulos coiffeurs in private portraits, and their presence in society became so natural that they figure quite prominently on Flavian and even on Traianic state reliefs (figs. 3-4). ${ }^{17}$ With Hadrian, the moralising attitude of the conservative party lost influence to such an extent that the habit of wearing a beard and elaborate hairstyle became a general fashion for all strata and age groups of society. ${ }^{18}$ While Hadrian's beard and hairstyle were connected primarily with luxury, this habit obviously did not - or rather, could no longer - contradict his position as emperor. The same holds true for his immediate successors and even for Marcus Aurelius, whose commitment to his duties as emperor is well attested, and whose luxurious style of hair and beard is equally unparalleled among Greek philosophers, in spite of his undisputed interest in philosophy (fig. 8). ${ }^{19}$ Smith has therefore argued that Hadrian's outer appearance was in accordance not only with his graecophilia but also with his political choices, and in particular with his renunciation of Trajan's expansionism and preference for the military. ${ }^{20}$ It represented the change from Trajan's traditional Roman simplicitas and military virtus, to Hadrian's urban elegantia, urbanitas, and civilitas. ${ }^{21}$ From one of Artemidorus' interpretations of dreams

15 Cain, 1993, 100-104.

16 Zanker 191-192 fig. 107.

17 Cancelleria reliefs: Bonanno, 1976, pls. 131-133; Arch of Titus: Bonanno, 1976, pls. 147; 149; Arch of Beneventum: Bonanno, 1976, pls. 170; 176-177.

18 However, Smith, 1998, 83-87, rightly stresses that clean shaving was still an option well into the Antonine period.

19 Smith $1998,90$.

20 For a convenient summary see Bierley, 1997.

21 Smith, 1998, 62-63; $91-92$ with due reference to the Historia Augusta in n. 187. However, I wonder whether the distinction between the circumstances in Rome and in the Greek East should really be carried as far as Smith wants, for the following reasons: (1) It may be no mere coincidence that the adoption of a beard by a wider sector of society already before Hadrian's reign, and a relaxed or even positive Roman attitude towards other practices and occupations regarded as Greek, occurred more or less at the same time, independently of Hadrian's motifs for wearing a beard. (2) Even if some portraits of the Eastern Greek élite may have displayed a beard already in the first century $\mathrm{AD}$, it is again in the second that bearded portraits become popular in the Greek East. (3) Because of the antique prejudice that tends to identify luxury with Hellenism (and the other way round), it seems hard to separate the two. Thus, I can imagine that at the beginning, for Roman adults, opting for a beard may well have been facili- 
we might infer that, in the second century, a luxurious style of hair and dress was also a status symbol:

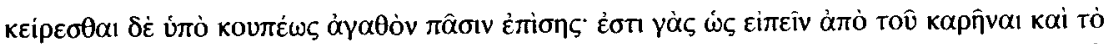

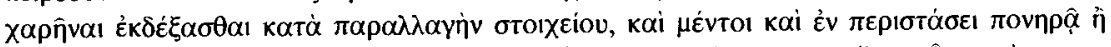

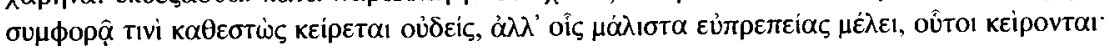

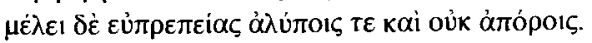

To have one's hair cut by a barber is good for all alike. For it is, as it were, from к $\alpha \rho \hat{\eta} v \alpha_{1}$ (to have one's hair cut) that we get the word $\chi \alpha \rho$ n̂vol (to rejoice) by the substitution of a single letter. Furthermore, no man who is involved in an unfortunate situation or in a calamity has his hair cut. Rather, it is people who are especially concerned about their appearance who have their hair cut. And a neat appearance is the concern of those who are free from pain and are not in difficulty. ${ }^{22}$

At the same time, a decidedly philosophical style would not have been appropriate for an emperor at all. The only way to make a 'real' philosopher recognisable in a portrait would have been to follow the cliché of how such a person would look like. According to this stereotype, his outer appearance would have to show neglect for personal hygiene, in particular through his unkempt hair and wildlygrowing beard - features hardly compatible with the position of an emperor or a member of the élite. ${ }^{23}$ But even without this visual problem, a member of the élite would hardly have wanted to be looked upon as a 'real' philosopher. Johannes Hahn has shown that, independently of his school, a real philosopher was a person with an appropriate $\beta$ ios, a lifestyle granting him a position at the margins of society. Only as someone who did not take part in the general competition for money, privileges and social status, could the philosopher live an exemplary life according to the highest ethical and moral standards, which would then allow him to exercise $\pi \alpha \rho \rho \eta \sigma^{\alpha} \alpha$, free speech and even criticism of social abuses. ${ }^{24}$ This marginality, however, could hardly have been something the ordinary Roman citizen, let alone a member of the social élite or an emperor, would have desired. Such an impression is supported by Dio's comment that the acbiton en bimatioi

tated by the fact that the majority of the Greeks of the past whom they admired, and whose portraits filled the houses and villas of the élite, wore beards as well; but this was irrespective of their occupation and therefore not suggesting a particularly philosophical image.

22 Artem. 1.22; transl. R.J. White. There is, thus, no reason to doubt that the positive attitude towards an appearance indicating learning and elegance, which we find in the Historia Augusta, reflects contemporary thought of the second century AD; cf. Smith, 1998, 91-92 with n. 187 quoting Hist.Aug., Hadrian 26; Aelius 5; Pius 2; l'erus 10.

23 Hahn, 1989, 33-45; Smith, 1998, 80-81. There have been, of course, philosophical schools whose philosophers looked as civilised as everybody else. However, nobody would be able to recognise them except by an inscription mentioning their status.

24 Hahn, 1989, particularly 182-191; 206-207; Flinterman, 1995, 162-193; Flinterman, this volume; for Latc Antiquity see. Brown, 1992. 
costume provoked mockery and even insult (72.2). It may be for this reason that we know of no statue depicting an emperor in the himation, not even Marcus. ${ }^{25}$

Then again, Zanker was by no means completely mistaken. There are some obvious imitations of famous Greeks from the Classical age, and it is certainly not just by chance that they are mostly from the second century AD. ${ }^{26}$ In the same period, portrait busts begin to show their patrons dressed in a bimation, often even without an undergarment. In late Republican and early Imperial Rome, the bimation was regarded not just as a Greek dress but also as a costume characterising a man as someone exercising a particularly Greek kind of learning. That the term Graeci palliati was used of philosophers teaching at Rome, makes this clear enough. For a Roman in Rome, the choice of bimation as the dress for a portrait sculpture carried analogous connotations - even more so when there was no tunic underneath. ${ }^{27}$ The bare chest could also signal ambitions towards paideia in the Greek East where the bimation was the customary dress worn even by Roman citizens, though usually on top of an undergarment. ${ }^{28}$ This intellectual' habitus was sometimes supplemented and emphasised by features which are more ambiguous but, in the context given, contribute to the overall picture. Facial expressions like the furrowed foreheads particularly common in the Antonine and Severan eras must represent some kind of thoughtfulness. ${ }^{29}$ To be sure, this thoughtfulness is not necessarily a philosophical one. When shown on a portrait with military dress, it may well refer to the patron's seriousness and military foresight, whereas on a portrait with a toga, it may refer to his political concern and responsibility. But when depicted in combination with a bare chest and bimation, its most obvious association will be with Greek paideia, and in this context also the beard will add to the overall picture of someone advertising his Greek education. The same is true of papyrus roles, so often depicted either carried in one hand or gathered in a bundle or in a box near the patron's feet. In a military context, like, for example, the adlocutiones on the columns of Trajan or

25 For the statues from Cyrene see n. 6 above; on private portraiture see below with n. 33.

26 Zanker, 1995, 209; 222-229 (I do not agree with Zanker's interpretation of his figs. 131-132); Krumeich, this volume; on a statue from (jortyn see also Smith, 1998, 81; cf. however Smith, $1998,78-79$ on Herodes Atticus' imitation of Greek citizens of around $300 \mathrm{BC}$ (not intellectuals in particular) and the bust of the Platonic philosopher Theon of Smyrna in a similar guise (Rome, Museo Capitolino 529: Inan - Alföldi-Rosenbaum, 1979, 162-164 no. 115 pls. 95; 105, 2. 4).

27 Zanker, 1995, 196; 216-221; Ewald, 1999a, 14.

28 This view is supported by the fact that not only in the West but also in the Hast, statues of contemporaries without a chiton are hardly ever found. For a possibly non-intellectual barechested image, see Smith, 1998, 71-73 on the monument of Philopappus at $A$ thens. 
Marcus, the rotulus will certainly refer to some military decree; in the hands of a togatus, it may well refer to some legal document. ${ }^{30}$ When in the hands of a barechested man dressed in a bimation, however, any viewer will most naturally interpret it as some document of erudition. ${ }^{31}$

Again, this erudition will not necessarily be of a philosophical nature. There are extremely few statues showing their patrons sitting on a chair in the hunched position typical of philosophers; 32 and it may be no mere coincidence that the bimation on a bare chest appears almost exclusively on busts or herms where its connotations are toned down by the abbreviated form, to a symbolic sign and a partial quality. ${ }^{33}$ For the Aphrodisian philosopher M. Aurelius Kallimedes, it was obviously sufficient to be acknowledged as a philosopher in the inscription on his sarcophagus, since he chose a non-philosophical civic image for his portrait. ${ }^{34}$ Hardly any portraits with the unkempt hair and neglected beard of the archetypal philosopher have come down to us. ${ }^{35}$ On the contrary, many of those who present themselves bare-chested and in bimation sport the typically luxurious hair-

30 In dextrarum-iunctio scenes, it is most probably the marriage contract (Wrede, 2001, 50). For togati on fourth century senatorial sarcophagi, Wrede has proposed to interpret the rotulus like the diptych - as some letter of official appointment (Wrede, 2001, 19 with n. 49; 88-89). The scrinium standing next to the patron's feet may refer to documents connected with his office in a more gencral sense, as the rotulus probably does, in scenes where the patron as magistrate is accompanied by an apparitor.

31 This is confirmed by the grave relief of Claudia Italia showing her with an open scroll in her

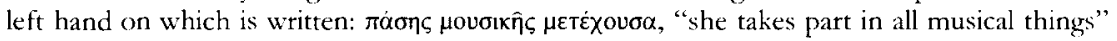
(Paris, Louvre, depot: Marrou, 1938, $75-77$ no. 71 pl. 3; Fwald, 1999a, 59).

32 Smith, 1999, 453.

33 Smith, 1999, 452 thinks that the scarcity of 'intellectual' statues is due to the fact that, in the Roman era, public statuc honours were hardly ever granted for intellectual achievements. However, as Smith himself has pointed out on various occasions, inscriptions on statue bases reflect not just the meaning of the statue above but often both elements' meanings supplcment each other. Accordingly, additional explanations must be provided. For an argument similar to my own see Smith, 1998, 64-65. - It is partly as a result of failing to recognise this important aspect (and for taking the Cyrene statues mentioned above n. 6 as proof of a gencral acceptance of the habit even in public representation of emperors) that Zanker (1995, 208-209) and Ewald $(1999,14)$ tend to overrate the philosophical component of paidea. Both do acknowledge that it is not just philosophers, but also poets, rhetors, teachers and others who wear the bimation; and both are aware of the fact that the paideia comprised various ficlds of knowledge (Zanker, 1995, 205-206; Ewald, 1999a, 16-18). However, I do not agree that this warrants their often synonymous use of the terms 'intellectual', 'philosopher', 'sage', 'teacher' etc., and the dangers become clear when, in the end, the philosophical aspect appears as the central one in their analysis of particular monuments (cf. also the title of Ewald's book: Der Philosoph als I eithild); cf. Raeck, 2002.

34 Hahn, 1989, 161-162; Smith, 1998, 81.

35 L..g. Zanker, 1995, 236-239 figs. 128; 130; cf. Smith, 1998, 80, who rightly reminds us of the fact that the lost busts or statues of these figures may still have downplayed the message. 
style of the Hadrianic to Severan periods (fig. 10). This combination has puzzled modern scholars, and even led to condescending characterisations of these people as merely pretending to an interest in philosophy while 'actually' being interested instead in fashion. ${ }^{36}$ Yet, in the light of recent research on Philostratus' sophists and the so-called Second Sophistic, these interpretations seem to be in need of some qualification. Interestingly enough, the outstanding characters whose lives Philostratus described in his bioi sophiston display the same combination of glamorous external appearance with serious, hard-earned learning. Rather unsurprisingly, for many decades they also met with disregard - if not blunt contempt - from modern classicists. More recently, though, scholars have argued that in antiquity they were highly regarded, with some of them even holding positions as senators, consuls and educators of emperors, like Herodes Atticus. The social status and success of these sophists is hardly understandable if their occupation was mere personal vanity, or if they were strange eccentrics fleeing from the real world, as some modern scholars have wanted to see them. Only if they served as positive role models and represented ideals (even if to an extreme extent), that they shared with the social elite of which they were a part, could they gain and maintain the position in society which they held. ${ }^{37}$ Moreover, this was not an internal affair of the Greek East: the success of their strategies at the imperial court suggests their acceptance in Rome as well. ${ }^{38}$

In portrait sculpture of the second century, we often find exactly this same combination of ostentation in outward appearance with a predilection for Greek education (fig. 10). Accordingly, these portraits confirm the interpretation just summarised, since it seems sensible to assume that the patron of a portrait intends to be presented in a positive way. ${ }^{39}$ Unfortunately, we know place and occasion of dedication for only a small percentage of sculptures. We may assume, however, that - at least outside Rome - a considerable number of them were set up in public places and some even on public commission. ${ }^{40}$ In Philostratus, Polemo is praised for being an adornment for his hometown Smyrna just

36 Such a suspicion still shimmers through some of Zanker's labels, e.g. fig. 132 (= our fig. 10): "Büste eines philosophierenden Stutzers", "bust of a dandy with philosophical pretensions".

37 Schmitz, 1997.

38 Flinterman, 1995, in particular 38-45; Flinterman, this volume; Champlin, 1980 passim; Greg Woolfs statement of a systematic failure in communication thus needs some qualification (Woolf, 1994, particularly 132).

39 Contra Zanker, 1995, 230-233.

40 For Rome see Alföldy 2001; for honorary statues for sophists proper see Bowie, this volume; cf. n. 33 above. 
like a splendid piece of public architecture would be, and this seems to be the ambition of the patrons of these portraits as well:

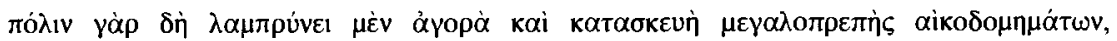

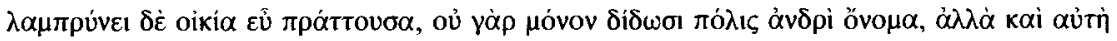

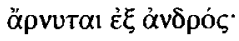

For just as its market-place and a splendid array of buildings reflect lustre on a city, so does an opulent establishment [with reference to Polemo's sumptuous style of travelling]; for not only does a city give a man renown, but itself acquires it from a man. 41

A look at the sophists may also help our understanding of why there are so few clear signs of the kind of intellectual activity referred to. Although Philostratus' sophists tend to specialise in certain fields of erudition - as do those personalities counted among the sophists by modern scholarship -, they typically know Homer as well as Plato and Demosthenes. Hence, it is unsurprising that we find only very few specifically philosophical costumes in portraiture. This undecidedness regarding any particular field of education is in perfect accordance with the general ideal of the pepaideumenos. ${ }^{42}$ Accordingly, Aulus Gellius, in the Antonine era, could still quote Ennius with approval: ${ }^{43}$

41 Philostr. VS 1.532, transl. W. Cave Wright. For Latin sources in a similar tenor see e.g. Fronto, Ad Amicos 1.4, a letter of recommendation to his friend Aegrilius Plarianus for Julius Aquilinus: Decet a te gravissimo et sapientissimo viro tam doctum tamque elegantem virum non modo protegi sed etiam provebi et illustrari. Est etiam, si quid mibi credis, Aquilinus eiusmodi vir ut in tui omamentis aeque ac nostril merito numerandus sit. " $A$ man so learned and so cultured should naturally find from a man of your serious character and wisdom not only protection but advancement and honour. Aquilinus is also, believe me, a man of such a character that he deserves to be accounted an ornament to yourself no less than to me." transl. C.R. Haines, emphasis B.F..B.); cf. the comment by Champlin, 1980, 33-34.

42 Therefore I do not agree with either Zanker, 1995, 230-233, or Smith, 1998, 80, that there are no sophistic-looking portraits but, on the contrary, I believe that the image of the pepaideumenos, of the citizen who uses his paideia as one of several elements of social distinction, corresponds to the sophistic image. On the unprivileged position of philosophy within the Roman conception of paideia see Champlin, 1980, 29-44; Hahn, 1989, 63-66.

43 Gell. 5.15.9 quoting Ennius (Fry. scen. 376 Vahlen); cf. Gell. 5.16.5 confirming his statement of 5.15.9 and Apul. Apol. 13. At one point even Dion Chrysostom advises the good ruler to take care to become a good orator and to study poetry, but not to carry philosophy too far; although this is not exactly in accordance with his general opinion that, in theory at least, the

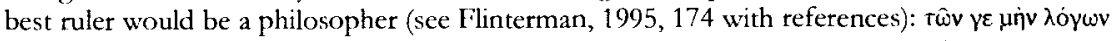

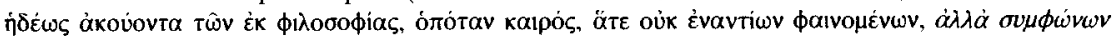

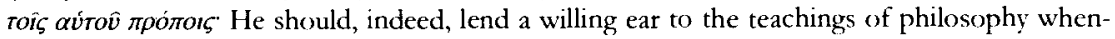
ever opportunity offers, inasmuch as these are manifestly not opposed to bis oun character but in accord with it. (2.26, transl. J.W. Cohoon; emphasis B.E.B.). Cf. Smith, 1998, 60; (Champlin, 1980, 2944 on the letters of Ironto; cf. Hahn, 1989, 63-66. 
Hos aliosque talis argutae delectabilisque desidiae aculeos cum audiremus vel lectitaremus neque in his scrupolis aut amolumentum aliquod solidum ad rationem vitae pertinens aut finem ullum quaerendi videremus, Ennianum Neoptolemum probabamus, qui profecto ita ait:

philosophandum est paucis; nam omnino haud placet.

When I heard of these and other sophistries [i.e. propositions by Democritus and Epicurus], the revival of a self-satisfied cleverness combined with lack of employment, and saw in these subtleties no real advantage affecting the conduct of life, and no end to the inquiry, I agreed with Ennius' Neoptolemus, who rightly says:

Philosophizing there must be, but by the few;

Since for all men it's not to be desired. (transl. J.C. Rolfe)

On the other hand, portrait sculpture can demonstrate the wide acceptance of those values and ideas embodied to an extreme extent in Philostratus' sophists and not only in the second century. The same preference for non-specialist paideia combined with an ostentatiously luxurious mode of dress continues well into the third and fourth centuries. To be sure, the long beard and ornate hairstyles of the Antonine era go rapidly out of fashion after Septimius Severus. However, at the same time, another, even more revealing kind of evidence steps in - sarcophagi. Their importance for social history and the history of ideas, and for the reconstruction of the ideals and outlook of Roman society, can hardly be overestimated. This is not just because of the large numbers of sarcophagi extant, but also because they continue to be produced through the second half of the third century, for which there is extremely little written evidence, whether literary, epigraphical, or even papyrological.

Already in the second century, sarcophagi with the nine muses document quite clearly the high esteem in which paideia was held, and, to be more precise, a paideia which incorporates a variety of fields (fig. 11). In contrast with the earlier Greek periods when the muses formed a more or less homogeneous chorus referring to poetry, from the fourth century $\mathrm{BC}$ onwards their characters are gradually differentiated until, in the Roman period, each of the muses can be associated with a certain field of competence, and has her own iconography representing her special area of expertise. ${ }^{44}$ Among the earliest examples are eight of originally nine wall paintings from a house in Herculaneum now in the Louvre. ${ }^{45}$

44 IIMC 6, 1992, 657-681 s.v. mousa, mousai (A. Queyrel); LIMC 7, 1994, 991-1013 s.v. mousa, mousai (1.. Faedo); IIIMC 7, 1994, 1013-1059 s.v. musae (J. Lnacha - L. Faedo); Wegner, 1966, particularly 93-110. This development seems important to me, although the differentiation is not always made explicit and the fields ascribed to a particular muse may vary.

45 Wegner, 1966, 96 Beil. 1-2. 
Inscriptions inform us about the names of the muses as well as their fields of competence, which are also indicated by their adornments. Apart from those muses referring to the various literary genres, we also find Clio for history (KAEIW ICTOPIAN) and Urania pointing with a stick at a globe, designating astronomy. The nine muses on the sarcophagi represent a large variety of spheres of knowledge which the deceased claims for him- or herself. ${ }^{46}$ On some of the short sides of these sarcophagi, we also find bearded males in himation, sometimes bare-chested, sitting, and/or carrying a papyrus role, supplementing the types of knowledge represented by the muses. Some of them carry gnarled sticks like the typical philosopher, and two sarcophagi even show recognisable philosophers, Socrates and Diogenes (fig. 9), ${ }^{47}$ representing the philosophical aspects of paideia. However, their lateral, even marginal position in the decoration as a whole, indicates that philosophy has by no means a particularly prominent status, and it would be rash to call all the bearded men collectively philosophers as is often done. Most of them do not show any of the iconographical features unique to philosophers. ${ }^{48}$ Some even wear a tunic or are accompanied by decorations such as theatrical masks, sundials or globes and thus refer explicitly to fields not at all, or at least not a central part of, a philosopher's occupations.

In the third century, there is an increase both in the number and the variety of pepaideumenoi depicted on sarcophagi. ${ }^{49}$ The most comprehensive representations show all the nine muses in standardised iconography with their respective attributes and thus again underline the variety of fields of knowledge included in paideia. ${ }^{50}$ When combined with older, bearded male figures, this may well suggest that the fields include philosophy, but perhaps also rhetoric and other disciplines, for which there is no muse available. Their more central position in the iconography may also indicate an increased importance of these spheres compared with the second century. ${ }^{51}$

46 On these sarcophagi see Wegner, 1966; Ewalcl, 1999a, 29-53 with bibliography.

47 Paris, Louvte Ma 475: Ewald, 1999a, 135-136 no. Al pl. 1; 2, 1-2; 3; Malibu, J. Paul Getty Museum 81.AA.48: Ewald, 1999a, 136 no. A2 pl. 2, 3; for a discussion see Ewald, 1999a, 8485.

48 The interweaving of terminological imprecision and confusing interpretation mentioned above $n .33$ becomes clear when Ewald $(1999,31-33)$ calls these men philosophers, thinkers, and typified intellectuals all at the same time.

49 Zanker, 1995, 252-272; Ewald 1999 passim, who rightly stresses that the iconographies of the third century are also much more explicit than those on the mythological sarcophagi of the second century (pp. 77-79).

50 Cf. the inscription on a scroll mentioned above $n$. 31 stressing the patron's knowledge in all fields supervised by the muses.

51 Ewald, 1999a, 33-34 and passim. 
Other patrons opt for abbreviations of this scheme, either for the sake of clarity or to make space for additional messages. When strigilated sarcophagi show, in the centre, a husband and wife in the typical marriage-concordia scene ${ }^{52}$ or making a communal sacrifice, flanked by the wife as muse and the husband in bimation on both outer edges (fig. 12), I find it hard to believe that this scheme refers only to the "philosophical counselling and moral conduct" on which the marriage is supposedly based. ${ }^{53}$ There is nothing in the iconography of the pepaideumenos that identifies him particularly as a philosopher. Rather, the ideals and values the couple is most proud of are divided between the two, and expressed through the most simple and clear iconography: The wife must be a muse since muses are female, and, as a single muse, she comprises all the fields of competence the muses stand for. ${ }^{54}$ The husband presents himself as pepaideumenos in the broadest sense, with the bare chest possibly hinting at the philosophical component of his education. His thetorical skills, so central to any Roman's education, are expressed by the gesture of his hand, as in so many other cases. ${ }^{55}$ Hence, I would prefer to see the two figures not as indicative of a reduction in meaning but as a kind of iconographical abbreviation, which incorporates a whole range of meanings and leaves space for other, complementary images. ${ }^{56}$ The iconography is thus still in line with other examples of a reduction in the number of muses.

Some patrons even dispense with the muses altogether, condensing the motif of paideia into a single figure. The famous 'sarcophagus of the brothers' in Naples

52 For its significance cf. Wrede, 2001, 30-31; 34-35; 43-50 with bibliography; I do not, however, agree with his interpretation of the popularity of that scene as an indication of an increasing importance of private happiness.

53 Ewald, 1999a, $57 \mathrm{~F} 1$ pl. 68, 3-4; 69, 2; Ewald, 2003, 568-569; characterised as philosopher without any more detailed commentary in Wrede, 2001, 61. The narrow meaning given to the figures by Ewald (op. cit.) seems somewhat surprising in the light of his convincingly open interpretation of anonymous groups of bearded male 'Denker' sitting on a stool accompanied by a muse in Ewald, 1999a, 42-47. As will become clear in the following, I also do not agree with Zanker's general interpretation of third century images of paideia relating them not to public life but to "persönliche Überzeugungen" and "ein Sich-Bekennen zu einer Lebensform" (1995, 252-272, quote on p. 253), although this interpretation seems plausible for sarcophagi with bucolic elements (ibid. 267-272).

54 Ewald, 1999a, 36, who rightly observes that the iconographical type chosen for the wifemuses is very often that of Calliope, leader of the muses, and thus their "universellste Vertreterin". On the Munich sarcophagus pl. 8, however, the wife has the attributes of Urania, which lay an unusual stress on astronomy.

55 Cf. Raeck, 2002.

56 This interpretation may also help to explain the surprising fact that in many groups of an 'intellectual' with muse it is not the muse who inspires the pepaideumenos but the pepaideumenos teaching the muse who just listens to him; on these images see Ewald, 1999a, 44-45. 
from the Gallienic period, presenting its patron in four different roles, is a good and well known case in point (fig. 14). ${ }^{57}$ On the left, the largest scene, showing the patron in the most representative form of toga surrounded by two lictores and two more apparitores, makes it clear that the patron is most proud of his status as a high-ranking holder of senatorial office. On the right, we find the familiar scene of husband and wife in dextrarum iunctio embraced by Concordia in the background, flanked by Venus on the right and the Genius Populi Romani on the left. Marriage thus appears as an exemplum for concordia and as one of the most basic institutions guaranteeing the preservation of the Roman Empire. In the centre, the deceased appears again in two single figures, one dressed in a simple toga and the other in Greek bimation with bare chest holding a papyrus role, as pepaideumenos. The paideia-motif is reduced to a single figure, in order to allow for other important aspects of the patron's status and personality to be illustrated. Its central position, however, demonstrates the importance of paideia even for high-ranking Roman officials. Its combination with other status-focussed images shows that this paideia is not a purely private accomplishment, but another status symbol, not (only) an element of otium but a prerequisite for the acquisition of any public office. ${ }^{58}$

While it may well be true that there was an increasing interest in philosophy and an urge for spiritual guidance, ${ }^{59}$ not long before the mid-third century, some images show a particular preference for philosophy, ${ }^{61)}$ although the patrons of sarcophagi continue to favour a more urbane look for themselves. A sarcophagus in the Museo Torlonia, probably from the $240 \mathrm{~s},{ }^{61}$ presents, arguably, the most decidedly philosophical attitude that we can find on sarcophagi of the third century (fig. 13). On the front its patrons are surrounded by eight muses and six bearded men of advanced age. The latter are dressed in bimation only: one has a gnarled stick, another carries a pouch (pera), and all of them display bodily features and wear their hair and beard in a way that indicates neglect for their outer appearance. Accordingly, they are rightly called philosophers. Their prominence

57 Ewald, 1999a, 54-56; 200-201 G9 pl. 88, 1; Wrede, 2001, 70-71 pl. 17, 1, both with bibliography.

58 Cf. Zanker, 1995, 264 with unwarranted reduction of the figure's meaning to the philosophical aspect; Ewald, 1999a, 55-56; 59 is more careful; Wrede, 2001, 75-76; 101-102.

59 Zanker, 1995, 252-272; Ewald, 1999a, 131-132 and passim with bibliography on the Aeioo àvin in n. 585; Ewald, 2003, 568-569; based on Veyne, 1987.

60 See in particular the palliati accompanying a magistrate, who, in the given context, may indeed be meant as the patron's personal philosophical advisor (Lwald, 1999a, 91-95) and all figures with decidedly (ynical iconography (Ewald, 1999a, 95-108 with my comment n. 62 below).

61 Rom, Museo Torlonia 424: Fwald, 1999a, 39-40; 95-101; 152 no. C1 pl. 24, 1-3; 25 with bibliography; Ewald, 1999a, 100-108 for sarcophagi with similar iconography. 
in the representation demonstrates the importance of philosophy for the couple and in particular for the patron, L. Pullius Peregrinus, significantly rounding off the number of philosophers to the canonical number of seven. ${ }^{62}$ Yet, he and his wife take care not to present themselves in the same guise as the figures they refer to. While the wife from the number of muses, the papyrus in her hand, and her Polyhymnia-pose, is obviously meant to be the ninth muse, her veiled head is in a decidedly Roman taste. ${ }^{63}$ Her husband reads from a papyrus and wears a bimation, presenting himself as pepaideumenos and, according to the number of philosophers, perhaps even as some sort of philosopher. But he wears a tunic as well, and the stool on which he is sitting is decorated and made more comfortable by a thick cushion. Apparently, he did not consider it appropriate for a centurio legionis of equestrian rank (which he was, according to the inscription on the lid) to present himself as a philosopher proper.

Others - and I would argue that this is the majority - still prefer to draw upon the whole range of aspects of paideia. ${ }^{64} \mathrm{~A}$ sarcophagus in the Vatican from around 280, once even thought to belong to the Neo-Platonist Plotinus, is a case in point (fig. 15). ${ }^{65}$ In the centre, the patron is portrayed sitting on a katbedra elevated by a platform. In his hands, he holds an open scroll, from which he has just stopped reading. A scrinium and a bundle of more scrolls lie beside his feet. On his right and left stand two female relatives with portrait heads, presented in the guise of Calliope and Polyhymnia respectively. Between the patron and the left 'muse' as well as at both outer edges, there are three anonymous elderly bearded men in bimation. While it is obvious that the relief demonstrates the

62 Zanker, 1995, 256-258 fig. 147; Ewald, 1999a, 96-98 rightly stresses that in spite of their number they should not be identified with the Seven Sages because the number of seven was canonical for other types of 'intellectuals' as well (cf. Gaiser, 1980). But though Ewald, 1999a, 98-101 is certainly correct in saying that their iconography is that of Cynics (in three cases decidedly so), I would nevertheless hesitate to identify them as Cynics and to draw far-reaching conclusions from their supposed representation, on the acceptance of Cynics in Rome of the third century (Ewald, 1999a, 106-108). Rather, it simply happened to be the case that Cynical iconography became the dominant iconography for the stereotypical philosopher, and thus was the only way of marking philosophers off from other intellectual palliati (for some qualification of his statement quoted above see also Ewald, 1999a, 104-106).

63 Figures of this type are called 'Musen-Matronen' by Ewald, 1999a, 43.

64 This is, of course, not to deny any variation concerning particular preferences. Whereas a few sarcophagi do indeed show a clear preference for philosophy (e.g. the Torlonia sarcophagus just discussed or Ewald, 1999a, 57; 199-200 G5 pl. 66, 2), others seem to focus on poetry or even on particular forms of poetry (e.g. Ewald, 1999a, 49; 172-173 E2 pl. 50, 1. 3) or display a preference for astronomy (c.g. Ewald, 1999a, 49; 177 E. 15 pl. 60, 1).

65 Rome, Musei Vaticani, Museo Gregoriano Profano 9504: Ewald, 1999a, 93-94; 167-169; no. D3 pls. 42, 1-2; 43, 1-4 with bibliography. 
paideia of the patron and his family, the usual interpretation that the patron wants to be seen as a philosopher, or just as being particularly interested in philosophy, is much less evident. Again, the 'muses' refer to the whole range of their competence, and these associations in turn relate not just to the two ladies but also to the patron they are flanking. Of the three bearded men, only the left one wears his himation on a bare chest. Since his balding head also seems to be imitating the portrait of Socrates, he must be a philosopher. The other two, however, wear a tunic under their bimation, and the hair and beard of the right figure at least are carefully curled. The contrast between these two and the philosopher on the left makes them appear even less philosophical, and marks them off as experts in different fields. ${ }^{66}$ The pose and gestures of the patron in the centre clearly point to his rhetorical skills. Finally, the patrons again take care not to appear too philosophical, and appropriately Roman. Both 'muses' have their heads covered. The pepaideumenos on his kathedra, although his mantle is draped like a bimation, not only wears a tunic underneath, but even substitutes the himation for the toga. On his feet, he quite clearly wears Roman shoes, demonstrating his equestrian rank. .7 $^{7}$

\section{Conclusion}

Our survey of portrait statues, busts and sarcophagi of the first three centuries $\mathrm{AD}$ has shown that self-representation in these media did indeed highlight their patrons' education and Greek paideia, as expected both from the general importance of self-representation in portraiture, and the significance of paideia for elite status which can be inferred from written sources. Four aspects concerning these references to paideia and its forms have also become apparent:

(1) The present survey, focussing on Roman monuments, has demonstrated that the ideal of paideia was by no means limited to the Greek East, but from the second century onwards was also accepted in Rome; a more comprehensive treatment would be able to show how widely so. ${ }^{67}$

66 Contra Zanker, 1995, 261-262 and Ewald, 1999a, 94 who want them to be philosophers of different schools.

67 Fittschen, 1972, 491-492, already observed that the figure type of the equestrian is taken from monarchical and magisterial representations, not from philosophical iconography. Quoted with approval and supplemented with further evidence by Ewald, 1999a, 38-42.

68 For the wide acceptance of this ideal among the members of society who could afford sarcophagi, see Ewald, 1999a. It would be extremely interesting to compare the situation in Rome with that in Greece and Asia Minor respectively. Yet, Roman portraits from Greece as well as sarcophagi from both areas still await an adequate publication and, at any rate, such a 
(2) Including sarcophagi in the discussion has permitted us to extend the survey through the third century $\mathrm{AD}$, despite a scarcity of written sources in its latter part. Contrary to the modern view that there was a decline in education and a lack of interest in it, the sarcophagi show both that a steady or even growing interest in paideia took place, and that a sophisticated and varied visual language developed. ${ }^{61}$ Sarcophagi provide a link between the age of Philostratus' sophists and Late Antiquity, revealing the continuities between these periods which are so often treated as separate by modern scholarship. ${ }^{70}$

(3) The iconography, in the vast majority of cases, does not indicate any preference concerning one particular field of paideia. It is not our failure that we cannot distinguish between different types of 'intellectuals,' nor is it a failure of the ancient artist to mark these types off more clearly. Where there was a certain preference on the part of the patron concerning his paideia, this is demonstrated by the addition of figure types which were characterised more clearly as philosopher, poet, orator, astronomer etc. ${ }^{71}$ However, it seems telling that such cases are rather rare. People knew what a Socrates, a Plato, and a Cheilon, a Euripides and Menander or a Demosthenes looked like, as is well demonstrated by copies of their portraits decorating houses, villas, and other places. Thus, it would have been easy to show a famous philosopher, poet etc. next to the deceased, either as a whole figure or as a tondo or herm portrait, just as they did in their private houses. But while some patrons of sarcophagi did indeed employ these devices, the majority chose not to do so. I am not suggesting that every single patron deliberately decided to 'have it all'. Rather, the very scarcity of cases where patrons emphasised a particular aspect of paideia suggests that the common ideal was paideia in a generalising sense, encompassing a variety of 'disciplines'. The indifference in iconography towards the exact content of paideia is thus both purposeful and adequate, since it includes all possible forms of paideia that a

project would have exceeded the scope of this paper. At first glance the material suggests that reference to paideia is indeed made, but that the actual manifestations of it differ from those in Rome. CE. Ewald, this volume, on Attic sarcophagi, and Smith, 1998, on differences in portraiture of East and West (with a slightly different focus).

69 Contra Raeck, 2002, 65.

70) However, this applies predominantly to those scholars focussing on the High Imperial age whereas studies on Late Antiquity tend to be more aware of continuities. Cf. in particular Brown, 1992; most recently: Swain - Edwards (eds.), 2004, and Drecoll, this volume, both with further bibliography.

71 Cf. Ewald, 1999a, esp. 84-109. 
patron might claim for him- or herself. ${ }^{72}$ It is in perfect accordance with what we know from other sources about attitudes towards paideia, and the forms in which it was appreciated and practised by the Roman élite, whose educational ideal is a comprehensive one.

(4) One of the most remarkable and, for a long time, most controversial aspects of Philostratus' sophists is their combination of a high standard of paideia with glamorous public performances. Portraiture often presents us with exactly this same combination and thus supports the view expressed by Thomas Schmitz and others, that the sophists were not just a crazy bunch, but rather, were the exponents of an ideal, which formed part of the culture of the élite in general. While portraiture of the second century expresses elements of luxury and display through the time-consuming hair and beard fashions it depicts, third century sarcophagi often show the pepaideumenos well-dressed, sitting on a cushioned chair or standing in a representative pose. The patron of the so-called Plotinus sarcophagus (fig. 15), one of the largest and most splendid pieces that has come down to us, presents himself in a highly imposing posture, with the flanking figures serving as an appropriate framework. The sarcophagus thus shows the same preference for ostentation and luxury, combined with competence in a wide range of intellectual fields, as Philostratus' sophists did. The fact that the patron himself and the two relatives present themselves clearly in Roman attire as well (the ladies capite velato, the patron in toga and Roman shoes), makes it clear that this ideal was no prerequisite of the Roman East, but had also become an important marker of status in Roman society of the capital. Others employ different devices but express a similar attitude. The patron of the Naples' 'brother sarcophagus' (fig. 14), refers to his paideia through his depiction in the modest dress of himation on bare chest, while ostentation and luxury are added through the flanking scenes, with the most representative of all clearly being the left one showing him in the toga contabulata surrounded by apparitores. The ideal of Greek paideia had spread over to the Roman West as an important indicator of status and an indispensable attribute for any Roman citizen with public ambition - even senators. ${ }^{73}$

72 So Hölscher, 1982, 213-215 (quoted by Ewald, 1999a, 81) is still right even after a more comprehensive study of the relevant monuments, which he demands, was carried out by Fwald, 1999a. The latter was able to make some valuable qualifications however.

73 For the second century, cf. the letters of Fronto, for instance, who recommends various friends for high posts including that of judge, governor, and even military service; see Champlin, 1980, 29-44. Cf. also Ewald, 1999a, 106 quoting Hahn, 1989, 175-176 who assumed that the concentration of written sources in the Roman Fast may be mere coincidence.

I would like to thank Frieda Klotz for improving my English. 


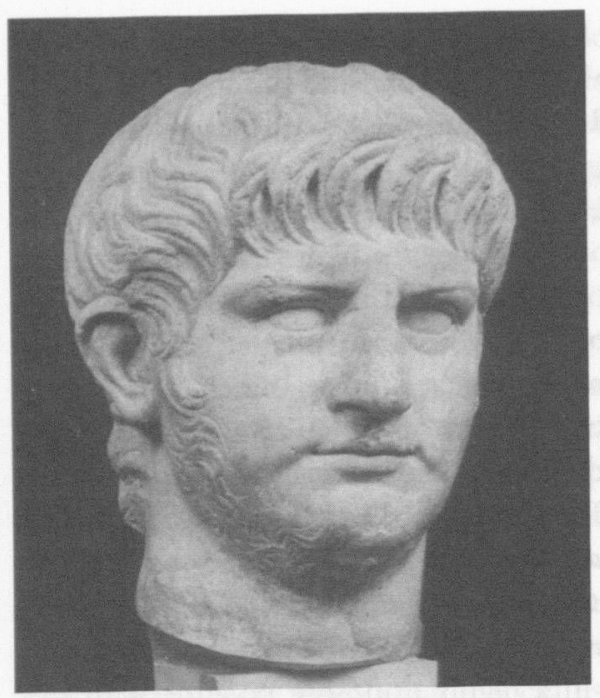

1 Portrait of the emperor Nero; Rome, Museo Nazionale 618

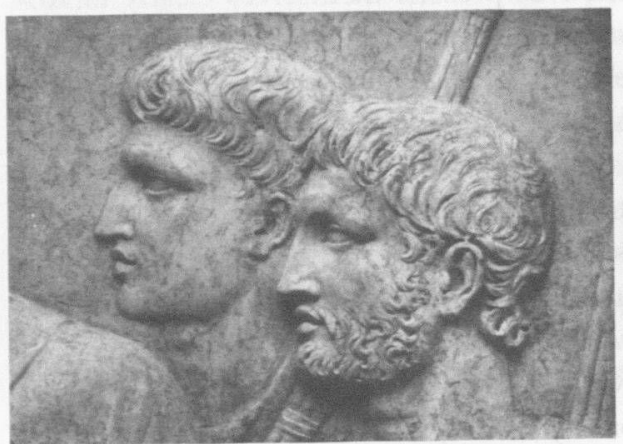

3 Heads of lictores on the Flavian Cancelleria Relief A

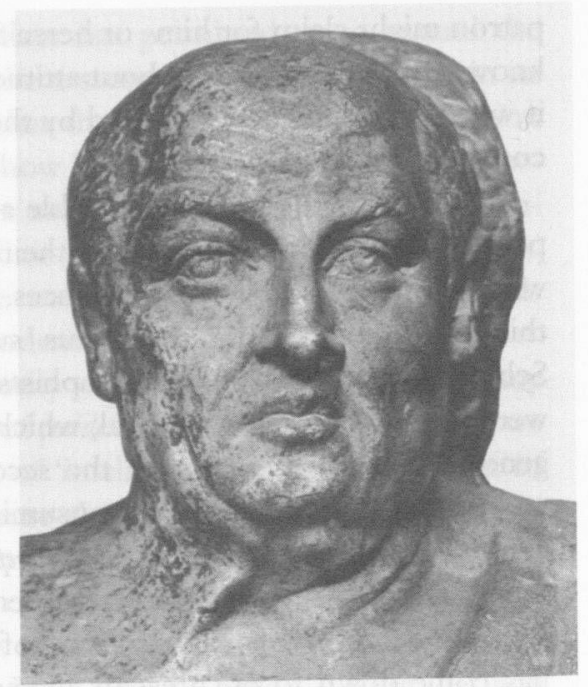

2 Portrait of Seneca, small double herm with Socrates; Berlin, Staatliche Museen 371

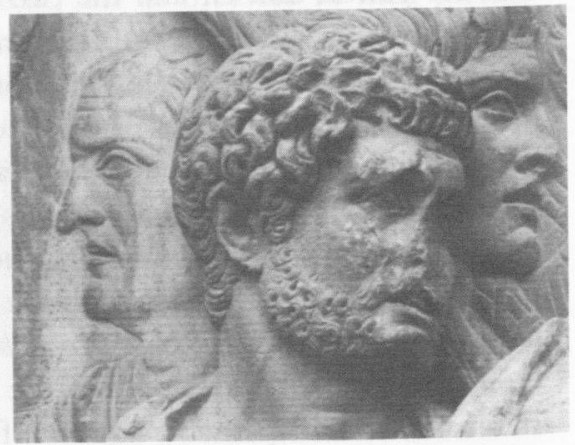

4 Officer behind the emperor on the Arch of Trajan at Benevento (NE front, lower panel) 

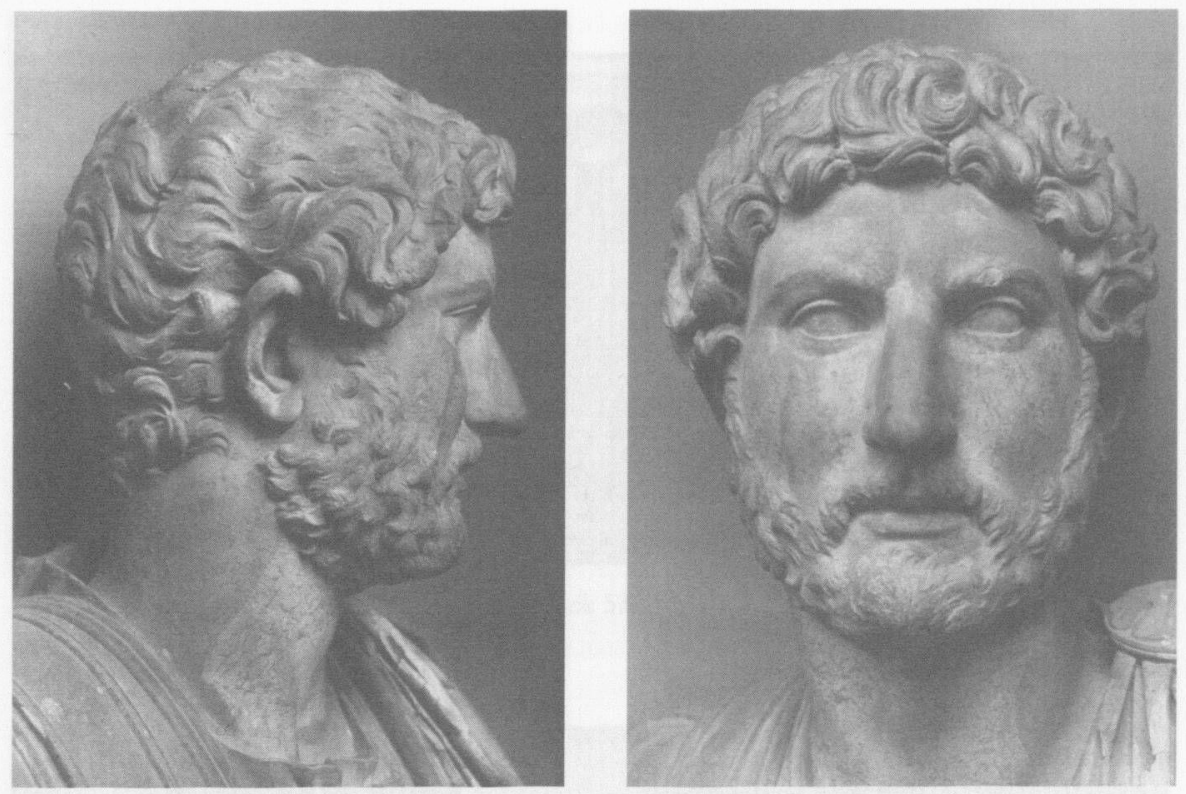

5-6 Portrait of the emperor Hadrian, Roma, Palazzo dei Conservatori 817

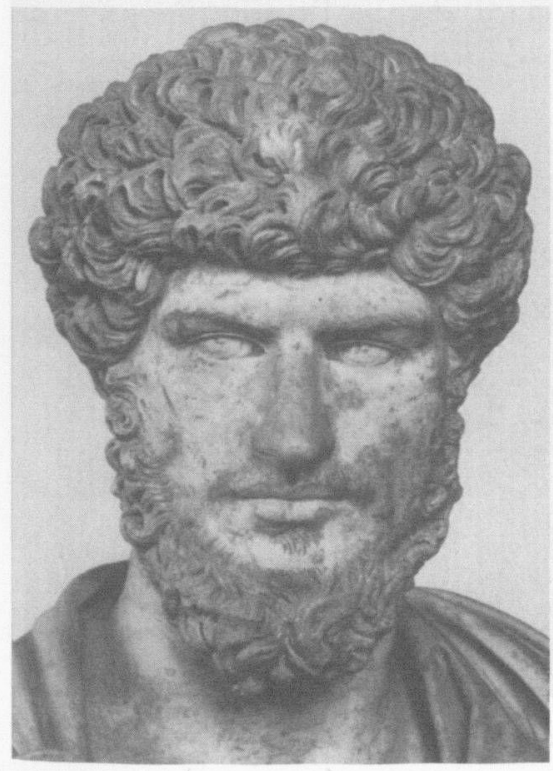

7 Portrait of the emperor Lucius Verus, Roma, Museo Capitolino 452

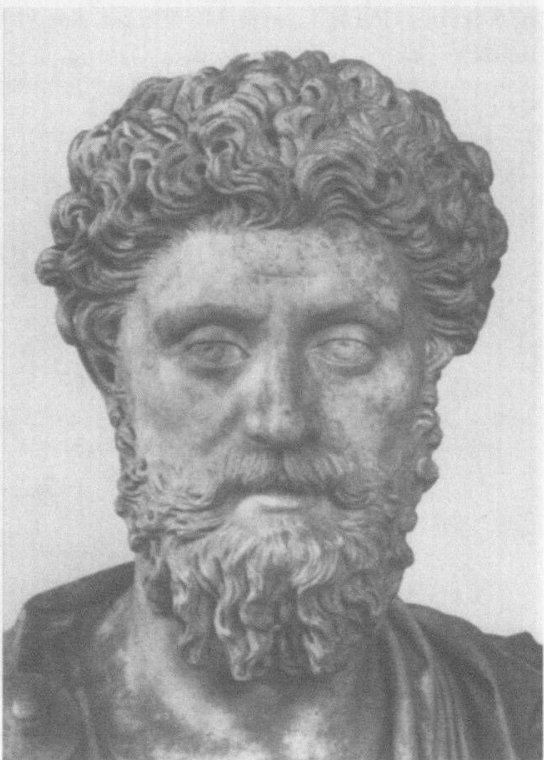

8 Portrait of Marcus Aurelius, Roma, Museo Capitolino 448 


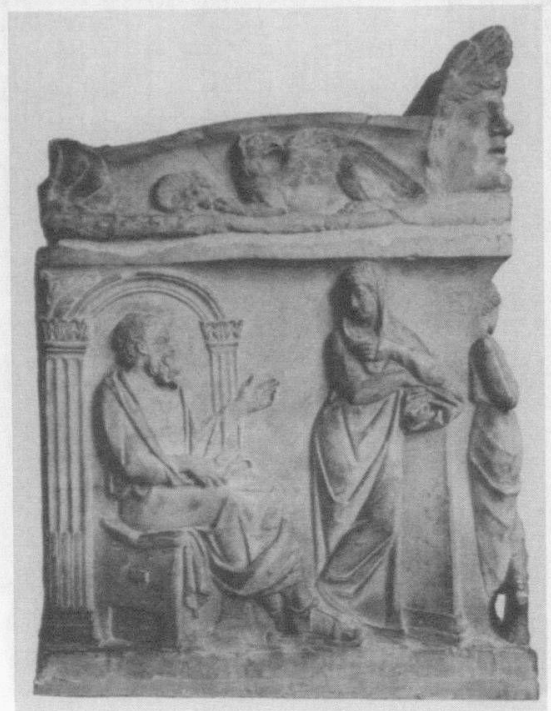

9 Short side of Sarcophagus with portrait of Socrates, Paris, Louvre Ma 475 (cf. fig. 11 below)

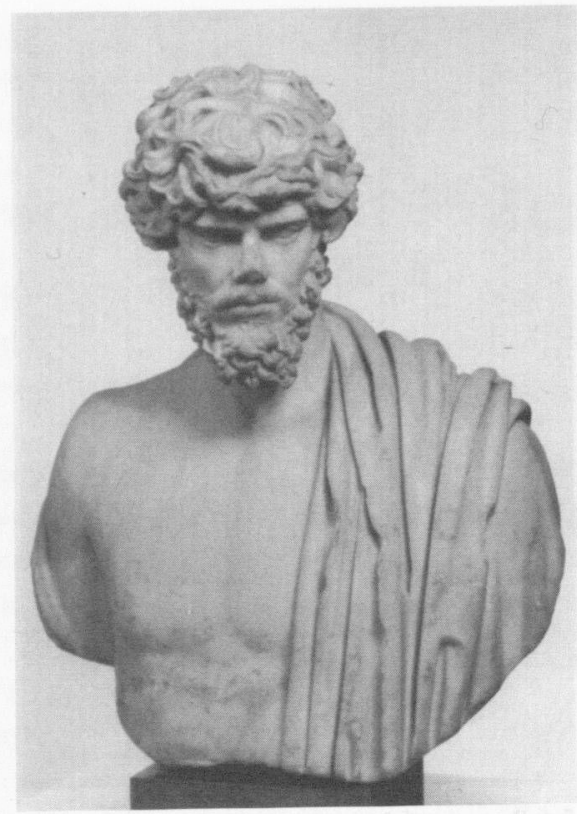

10 Bust of a joung man, Copenhagen, $\mathrm{Ny}$ Carlsberg Glyptotek I.N. 789

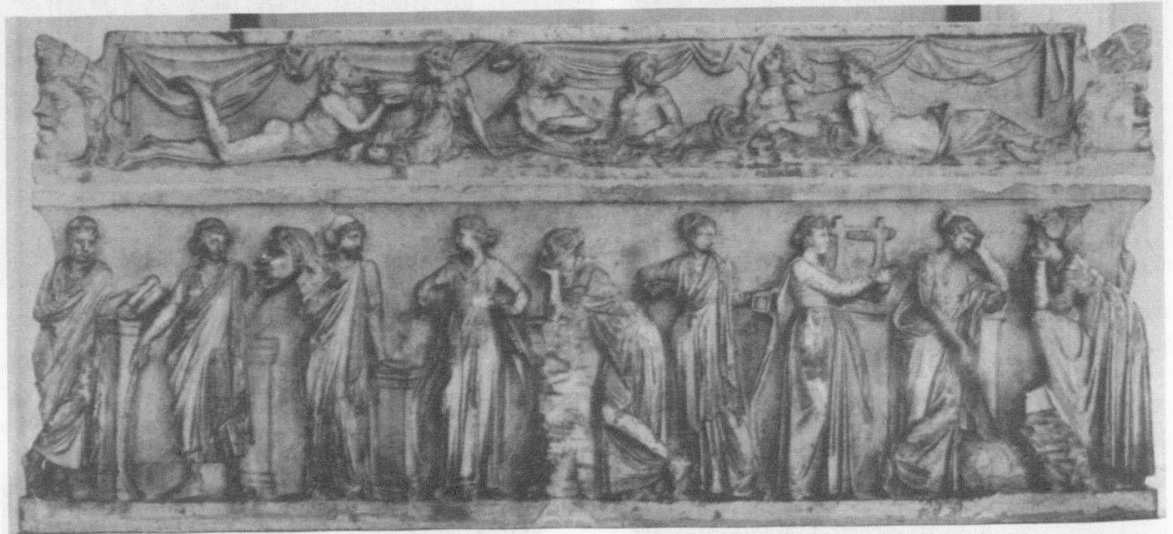

11 Sarcophagus showing the nine Muses, Paris, Louvre Ma 475 


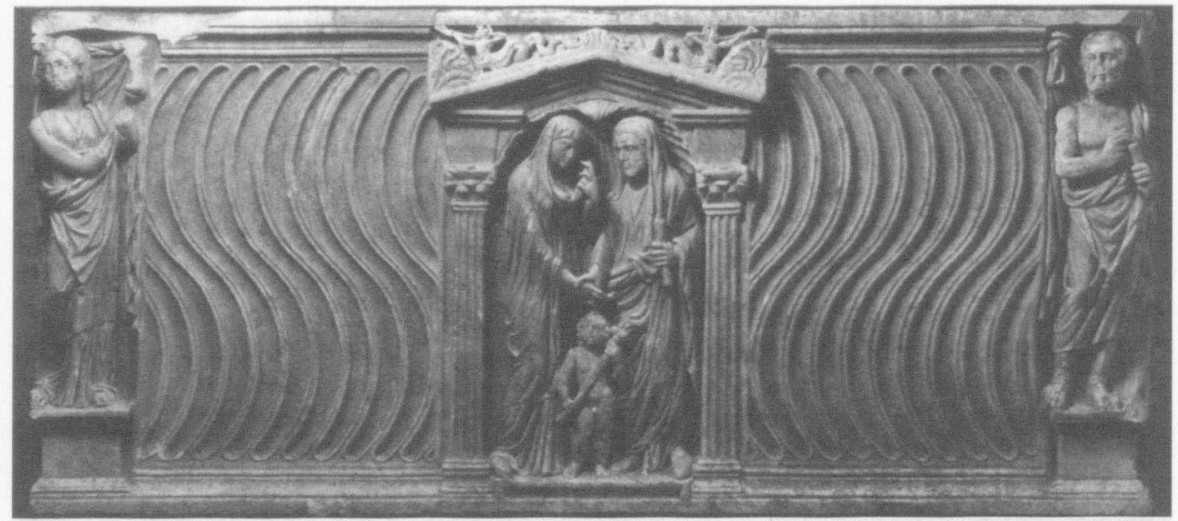

12 Sarcophagus of a couple: Munich, Glyptothek 533.

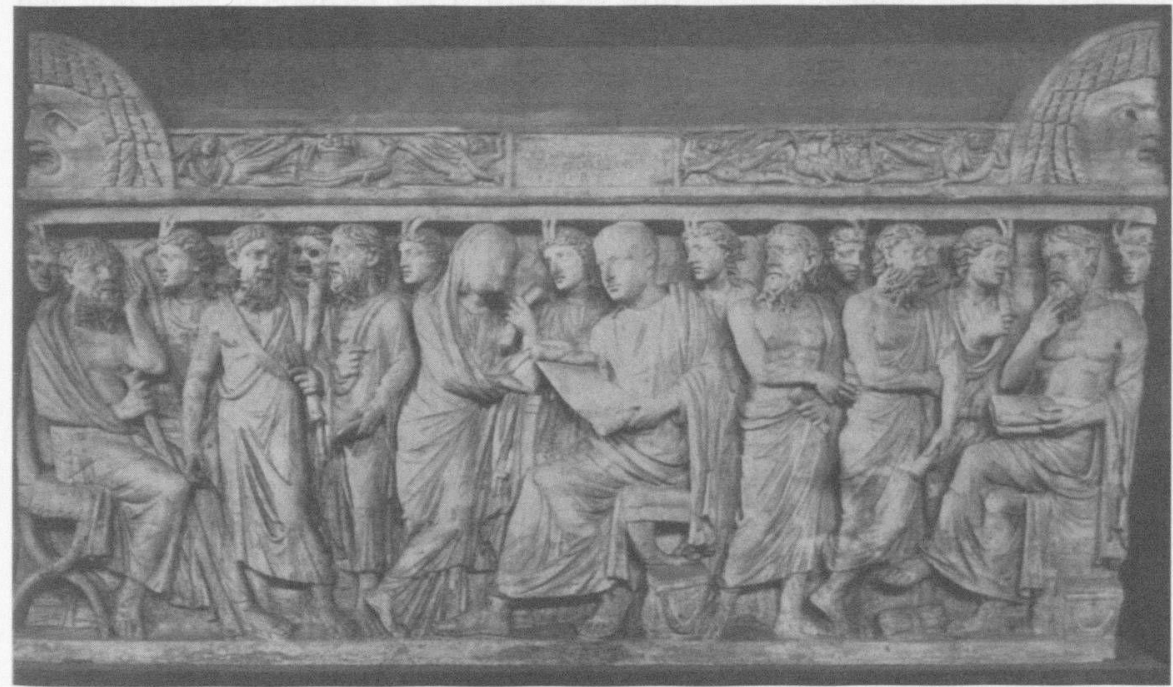

13 Sarcophagus of L. Pullius Peregrinus and his wife, with philosophers and Muses; Rome, Museo Torlonia 424. 


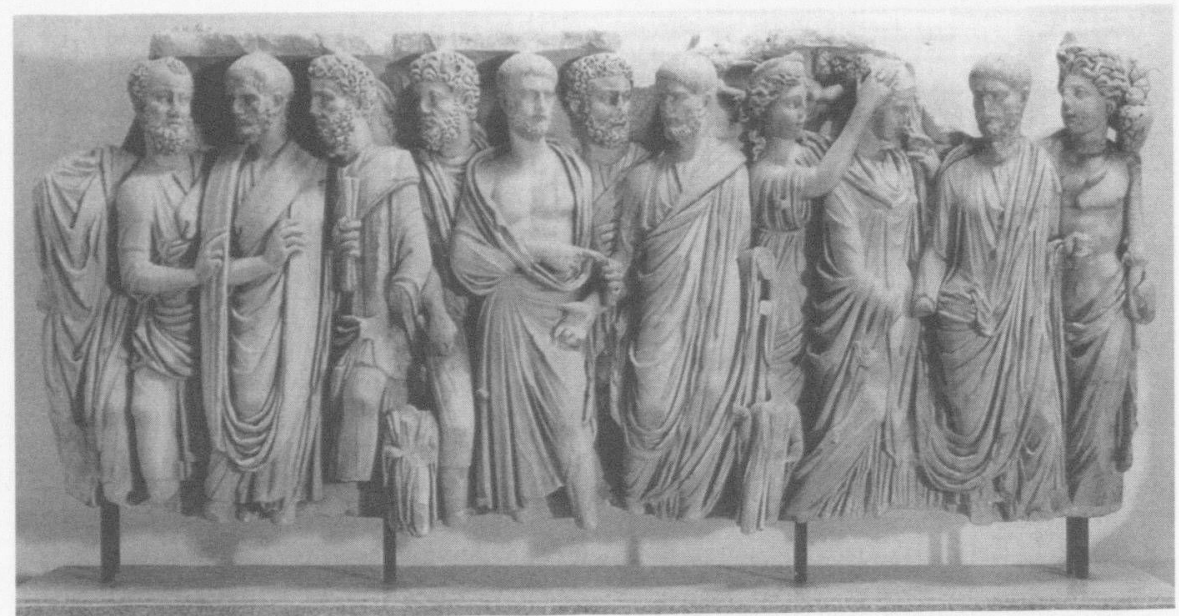

14 Sarcophagus of a senator (?), so-called 'brother-sarcophagus'; Naples, Museo Nazionale 6603.

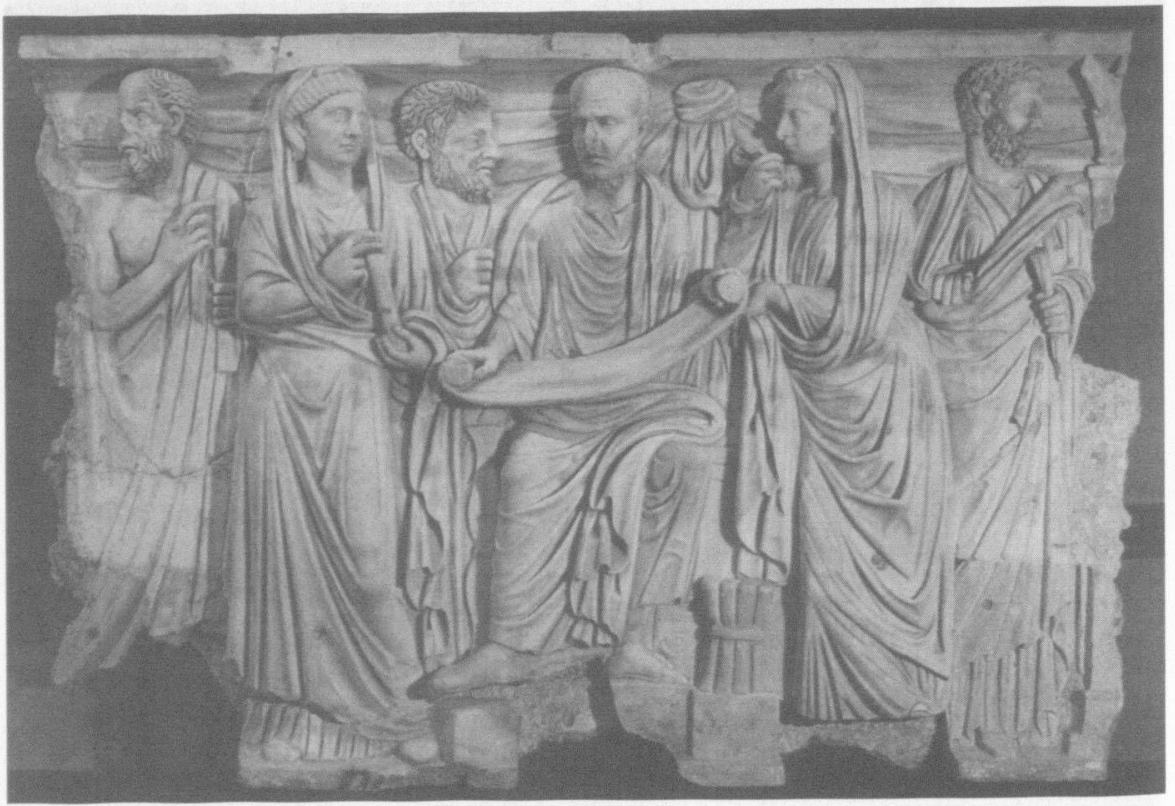

15 Sarcophagus of an equestrian and two family members, so-called 'Plotinus-sarcophagus'; Rome, Musei Vaticani, Museo Gregoriano Profano 9504. 